Original Research Paper

\title{
The Mutual Relationship Between Corporate Governance and Management Accounting: Which Occurs First?
}

\author{
Quang Linh Huynh \\ School of Economics and Law, Tra Vinh University, No. 126 National Road 53, Ward 5, Tra Vinh City, Vietnam
}

Article history

Received: 03-06-2015

Revised: $10-07-2015$

Accepted: 14-07-2015

E-mail: huynhquanglinh@tvu.edu.vn

\begin{abstract}
This research focuses on the complicated relationship between Corporate Governance and Management Accounting. On the one hand, good corporate governance structure is a driving force of adopting management accounting techniques in business; on the other hand it is enhanced by the information derived from management accounting techniques. The mutual relationship between corporate governance structure and management accounting has been discussed and examined, but it is investigated separately. The current research investigates this mutual relationship for the publicly listed firms in Vietnam. By applying the advanced models of directed graph searches and directed acyclic graphs, this study examines the mutual relationship in a joint model. The findings confirm that good corporate governance structures are first the causality of adopting management accounting techniques in business. Then, these management accounting techniques will help to result in better corporate governance structures. The results provide researchers as well as managers with a better understanding of the complicated relationship between corporate governance structure and management accounting. This will help the managers build effective management accounting techniques, which match with their corporate governance structures, so that their firms can attain the possible best performance.
\end{abstract}

Keywords: Corporate Governance, Management Accounting, Directed Graph Search and Directed Acyclic Graph

\section{Introduction}

This research extends the notion of Bhiman (2009) that corporate governance and management accounting are increasingly and inextricably interdependent. Corporate governance structure is considered as the causality of adopting management accounting techniques in business (Cromie et al., 1995; Salvato and Melin, 2008; Christine et al., 2011; Wang and Huynh, 2014). Management accounting techniques are in contrast suggested as tools to enhance corporate governance structure (Kaplan and Nagel, 2004; Kaplan and Norton, 2007; Seal, 2006; Mayanja and Van, 2011). They imply that management accounting information is helpful in creating sustainable corporate governance. The relationship between corporate governance structure and the adoption of management accounting techniques has been discussed and examined in previous studies, but they explored this relationship in separate research models. Furthermore, corporate governance structure and the adoption of management accounting techniques are both deemed as the causation of firm performance (Mia and Clarke, 1999; Williams and Seaman, 2002; Nicholson and Kiel, 2007; Kaymak and Bektas, 2008). This is similar to the notion of Testa et al. (2014) and Sgroi et al. (2014) that the introduction of new techniques, tools or processes in an organization can help that organization achieve a competitive advantage over their competitors, which will leads to improved performance.

The mutual relationship between corporate governance structure and the use of management accounting techniques could impact on the process of generating performance for the firm. Hence, exploring the mutual relationship between these elements in a joint research model and determining which directed edge of the mutual relationship occurs first are especially important to the causation of firm performance that maintains the survival of the firm. This research tries to profoundly examine the relationship between corporate governance structure and the adoption of management 
accounting techniques by employing the advanced models of directed graph searches and directed acyclic graphs. The model of directed graph searches can handle data sets in which the underlying causal linkages are cyclic; whereas the directed acyclic graph analysis can decide which directed edge of the cycles occurs first, by letting each relationship only go in one direction, namely the dominant directed edge of the interrelationship. The essence of the mutual relationship becomes clearer with the models of directed graph searches and directed acyclic graphs. Furthermore, numerous studies have evaluated the relationship between corporate governance and management accounting, but most of them are focused on Western data. Only a few studies have been undertaken in Asian economies. As an Asian country, Vietnam is the most rapidly growing economy and a member of Southeast Asia as well as a member of the World Trade Organization (WTO). Additionally, Vietnam is the third most populous Southeast Asian country after Indonesia and the Philippines; it expects that its new status as a signatory member of the international trading system will make increasingly large contributions to the world economic growth. The dynamic and rapidly changing business environment enables firms in Vietnam pay more attention to effective management tools in order to create competitive advantages and achieve better performance. Given the significance of the above mentioned research gap, the current study explores the relationship between corporate governance and management accounting, focusing on the data derived from the publicly listed firms in Vietnam. This research is expected to add to a better understanding of the extent to which the findings in Vietnam, an emerging economy in Asia, are consistent with those in previous research.

This research is the first to employ the superior procedures of directed graph searches and directed acyclic graphs that would offer a greater understanding of the mutual relationship between corporate governance structure and the adoption of management accounting techniques to researchers as well as to managers. The findings indicate that the relationship between corporate governance structures and the adoption of management accounting techniques is complicatedly reciprocated. Good corporate governance structures first boost up the adoption of management accounting techniques in business, which will however help to create more sustainable corporate governance structures. The findings of the mutual relationship between corporate governance structure and the adoption of management accounting techniques could help managers to build effective management accounting techniques matching with their corporate governance structures, which eventually lead to sustainable performance. The research continues with the section "Hypothesis development", which summarizes the relevant literature and then comes to hypotheses, followed by the section "Data and method". The data and method introduces the way to measure the variables used in the research, how the data is analyzed, as well as the way to collect the data. Section "Empirical result" describes and explains the outcomes from the analyses in the subsequent section. Finally, Section "Discussion and conclusion" offers a summary of the research and gives some discussions.

\section{Hypothesis Development}

Corporate governance refers to the framework of rules, practices and processes that the board of directors apply to direct and control their firm for ensuring accountability, fairness and transparency in a firm's relationship with all its stakeholders including its shareholders, management, customers, suppliers, financiers, government and the community (Cadbury, 2000). Corporate governance is aimed at avoiding massive disasters before they occur. Following the 2002 introduction of the Sarbanes-Oxley Act in the United States, corporate governance has become a serious issue (Ameer, 2013). This Act was ushered in to restore public confidence in firms and markets after accounting fraud bankrupted high-profile firms such as Enron and WorldCom. After that event, most firms try to have a higher level of corporate governance. Well-executed corporate governance should be similar to a police department's internal affairs unit, weeding out and eradicating problems with severe prejudice. From the above mentioned underpinnings, corporate governance could be reckoned critical to the development of firms; therefore most firms strive to have sound corporate governance structures. Different firms have different corporate governance structures, which impact on firms' achievement. Corporate governance structure is to organize and manage firms, which concern the relationships among the firm management, its board of directors, its shareholders and other stakeholders. A study conducted by Mayer (1997) suggests corporate governance structure as "ways of bringing the interests of shareholders and managers into line and helping firms run for the benefit of shareholders, while Cadbury (1992) regards corporate governance structure as a monitoring mechanism to lessen the conflicts of interests among stakeholders by mitigating agency costs thanks to the separation between ownership and management as well as the majority of outside directors in the management board. This will help firms obtain competitive advantages over their competitors and, hence create sustained profitability and boost up firm performance.

Management accounting is a new approach to accounting. The term management accounting is composed of two words-management and accounting. It refers to accounting for the management. Management accounting relates to the provisions of accounting information to managers within firms 
that would offer them with the basis to make informed business decisions. This will allow them to maintain effective management over their firm resources. Hence, management accounting is vital to firms in controlling their business activities. Management accounting techniques are necessary for firms, because they provide timely and accurate information to facilitate the management of costs, pricing decision, as well as the measurement and enhancement of productivity (Johnson and Kaplan, 1987). In addition, Kaplan (1983) highlights that management accounting techniques play an important role in providing essential information for management planning to enhance firm performance. Previous studies (Otley, 1999; Fullerton and McWatters, 2001) have implied that the new techniques have affected the practices of management accounting in business in which they have turned the focus of management accounting from a simple role of financial control to an intricate role of creating value by better using resources. Furthermore, Lucas (1997) in the research on "Standard costing and its role in today manufacturing environment" emphasizes that, to survive in the rapidly changing business environment, firms should adopt as many management accounting techniques as possible, especially advanced management accounting ones rather than traditional ones. That research argues that traditional management accounting techniques, such as traditional budgeting, cost volume profit analysis and variance analysis, which are financially oriented, are not still regarded as too helpful tools to offer adequate information for the control of organizational activities in the current dynamic business environment. In addition to the traditional management accounting techniques, firms should refer to more advanced management accounting techniques, such as activity based costing, total quality management and balanced scorecard, for meeting the requirements of customers as well as other stakeholders. Similar to sound corporate governance structures, the information of management accounting also brings about competitive advantages to the firm. As a result, the choice and adoption of management accounting techniques in business plays an important role in cost reduction and quality improvement (Chand and Dahiya, 2010). That is because management accounting techniques are deemed to explore and manage the main profitability drivers (Mohamed and Jones, 2014).

Salvato and Melin (2008) recommend that the empowerment of firm management to independent directors with their excellent qualifications, proficiency and experience will lead to a high level of formalization. The independent directors ought to report their work to their shareholders; they hence need formal management tools to control effectively business operations (Cromie et al., 1995). In addition, Agrawal and Chadha (2005) find that the probability of restatement is significantly lower in firms whose boards or supervisory committees include outside independent financial experts, whereas higher in firms where chief executive officers hold the firm's major shares. Their findings are consistent with the argument that independent directors adopt more formalized management techniques, which create more faithful earnings reports. Furthermore, a study on "Corporate governance and management accounting in family firms" by Christine et al. (2011) implies that it is essential to set up a separate division in charge of management accounting, where formal management accounting tools should be employed for formalized management techniques. They also contend that outside independent directors tend to adopt more sophisticated accounting management techniques in their firms. In addition, Wang and Huynh (2014) have discussed and identified the positive effect of corporate governance structure on the adoption of management accounting techniques in business. Based on the above underpinnings, we can formulate the following hypothesis.

\section{H1: Good corporate governance structure will lead to the higher adoption of management accounting techniques in business}

Kaplan and Nagel (2004) contend that the information derived from management accounting techniques will enhance the effectiveness of corporate governance structure because it provides the directory board with necessary information for business management. Furthermore, this information could help corporate boards in offering useful suggestion to the chief executive officer, so that the chief executive officer can better fulfill their managerial job (Kaplan and Norton, 2007). Therefore, it is supposed that management accounting techniques could generate effective corporate governance by providing important information to manage business operations. The research on management accounting and corporate governance by Seal (2006) implicates that the techniques derived from management accounting can be adapted to embed better corporate governance structure, since good corporate governance structure is formed by supportive information obtained from management accounting techniques. The above arguments lead us to believe that management accounting techniques could shape corporate governance structure and hence, we can come to the following hypothesis.

\section{H2: The adoption of management accounting techniques in business will enhance corporate governance structure}

The above-proposed hypotheses lead to a proposed research model as described in Fig. 1, in which good corporate governance structures are suggested as the causation of the adoption of management accounting techniques that then leads to improvements in corporate governance structures. 


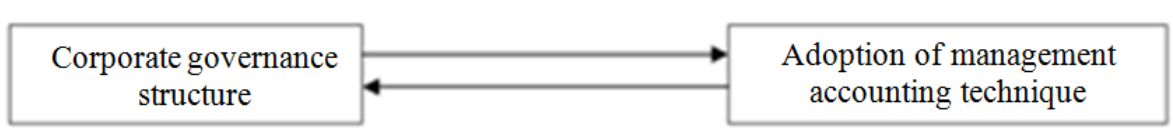

Fig. 1. Proposed research model

\section{Data and Method}

Grounded on the previous research (Brown and Caylor, 2004; Edwards and Clough, 2005; Black et al., 2006; Bhagat and Bolton, 2008; Cassell et al., 2012), Corporate Governance Structures (CGS) would refer to the composition of directorial board (CGS1), the independence of supervisory committee (CGS2), the duality of chief executive officer (CGS3), the disclosure of director candidates to shareholders in advance of shareholder meeting (CGS4), the permission of voting by mail (CGS5), the publicity of resumes of board members on website (CGS6) as well as the organization of investor related activities (CGS7). CGS1 takes 1, if the board has at least $50 \%$ outside independent directors; 0 otherwise. CGS2 is recoded as 1 , if the committee has at least $50 \%$ outside independent supervisors; as 0 otherwise. CGS3 is measured as 1 , if the positions of the chairperson and the chief executive officer are separate; as 0 otherwise. CGS4 is 1 , if the firm discloses director candidates to shareholders in advance of shareholder meeting; 0 otherwise. CGS5 obtains 1, if the firm permits voting by mail; 0 otherwise. CGS6 is 1 , if the firm includes resumes of board members on the firm website; 0 otherwise. CGS7 gets 1 , if the firm conducts investor related activities; 0 otherwise.

With regard to management accounting techniques, in concurrence with the viewpoints of Kaplan (1983), Lucas (1997) and Wang and Huynh (2014), the adoption of management accounting techniques in business is measured as the extent to which a firm adopts the management accounting tools for controlling business activities. A five-point scale is employed to measure the adoption of Management Accounting Techniques (MAT). The values range from 1.never considering, 2.decided not to introduce, 3.favored to introduce, 4.intended to introduce, to 5.under implementation of management accounting techniques, adapted from Cinquini et al. (2008). The index "MAT" consists of the following six elements, namely traditional budgeting (MAT1), cost volume profit analysis (MAT2), activity based costing (MAT3), total quality management (MAT4), variance analysis (MAT5) and balanced scorecard (MAT6), which is suggested by the prior studies (Kaplan 1983; Otley, 1999; Lucas, 1997; Hyvonen, 2005; Al-Omiri and Drury, 2007; Wang and Huynh, 2014).

The sample used for the research is firms publicly listed in the Vietnamese Stock Exchanges. In Vietnam, there are two Stock Exchanges, namely Ho Chi Minh
Stock Exchange and Ha Noi Stock Exchange. Ho Chi Minh Stock Exchange has 310 listed firms and Ha Noi Stock Exchange has 376 listed firms. These firms represent dominant industries in Vietnam as an emerging economy. A pilot test for measurements is carried out with 10 managers involved in corporate governance and management accounting to ensure that the scales employed for analyses are valid and appropriate for the study (Donna et al., 2011). An extensive survey of corporate governance structures and management accounting techniques applied in business was performed with all the 686 listed firms. There are only 333 responses with adequately required information, achieving the success rate of $48.54 \%$. The data from the 333 responses is processed with statistical techniques. First, a reliability analysis technique is employed to test the consistency of scales. The reliability analysis is used to assess the extent to which multiple measures of the same scale are consistent with one another (Nunnally, 1978). The correlations among individual items within the scale are provided. The scale will produce consistent and reliable results, if the item-total correlations are large. After the data is ensured consistent and reliable, it is analyzed with the analyses of directed graph searches and directed acyclic graph. Theoretical underpinnings from previous studies lead us to think that the mutual relationship is best effectively investigated with the models of directed graph searches and directed acyclic graphs. The model of directed graph searches can handle data sets in which the underlying relationships are cyclic, while the directed acyclic graph is a directed graph where there are no cycles. The former is applied to determine effect directions of the mutual link, whereas the latter is applied to decide which directed edge of the mutual relationship between corporate governance structure and the adoption of management accounting techniques comes first. Lastly, the regression analysis is used to test the effect of corporate governance structures on the adoption of management accounting techniques in business as well as the influence of the information derived from management accounting techniques on corporate governance structures.

\section{Empirical Result}

The two factors used for the purpose of this research are corporate governance structure and the adoption of 
management accounting techniques in business. Each of them is made up of multiple items. The reliability analysis is thus performed to examine the properties of the scales. The reliability analysis is a technique calculating a number of commonly used measures of scale reliability and offering information on the correlations among separate items in the scale. The itemtotal correlation of CGS7 is 0.351 (untabulated) smaller than 0.5 , the smallest level suggested by Nunnally (1978), although the Cronbach alpha value obtains 0.796 (untabulated) higher than 0.7 as a lowest limit stipulated by Nunnally (1978). As a result, this item is taken away from the data. Eventually, the 12 other items (six for each of the two factors) obtain good results for the reliability, as shown in Table 1. Accordingly, it is reasonably assured that all the remaining 12 items satisfy the reliability and so are suitably retained for further analyses.

The mutual relationship between corporate governance structure and the adoption of management accounting techniques is best investigated with the techniques of directed graph searches and directed acyclic graphs. First, the technique of directed graph searches with the LiNGAM algorithm is employed to explore the mutual relationship. The LiNGAM algorithm can handle data sets in which the underlying causal linkages are cyclic. The findings show that a number of nodes in the model is 2 , while a number of edges is also 2. Both of the edges are directed as described in Fig. 2. This implies that corporate governance structure is both the causation and the consequence of the adoption of management accounting techniques in business. The LiNGAM analysis cannot indicate which of the edges occurs first in the research model. To determine which effect direction comes first in this mutual relationship, the directed acyclic graph analysis is applied. This analysis is utilized to extract the first effect direction in the mutual relationship. The results indicate that the causal effect from corporate governance structure to the adoption of management accounting techniques occurs first in the reciprocal link as presented in Fig. 3. So far, it can be believed that the relationship between corporate governance structure and the adoption of management accounting techniques is mutual; and the effect of corporate governance structure on the adoption of management accounting techniques comes first in the mutual relationship. To check the robustness of the findings from the models of directed graph searches and directed acyclic graphs, this research performs the regression analysis to examine each direction of the mutual link. To carry out the regression analysis, the factors Corporate Governance Structure (CGS) and the adoption of management accounting techniques (MAT) are calculated by averaging their own items. The regression analysis produces the results displayed in Table 2. The findings reveal that Corporate Governance Structure (CGS) affects the adoption of Management Accounting Techniques in business (MAT) at a statistical significance of 0.01 with the 1.304 coefficient. The causal model achieves the goodness of fit at the significance level of 0.01 with the 89.101 F-statistics. In contrast, the adoption of management accounting techniques in business is statistically demonstrated as a driver of corporate governance structure at a significance of 0.01 with the 0.163 coefficient. The model fitness attains the statistical significance level of 0.01 with the $89.101 \mathrm{~F}$ statistics. These findings support the two proposed hypotheses that corporate governance structure and the adoption of management accounting techniques in business are mutually interacted.

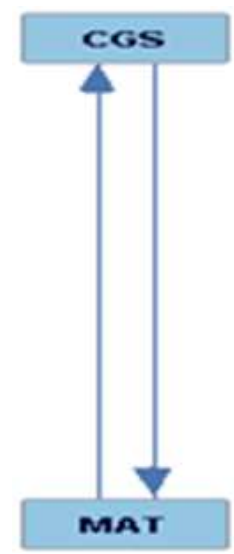

Fig. 2. Results from the directed graph searches

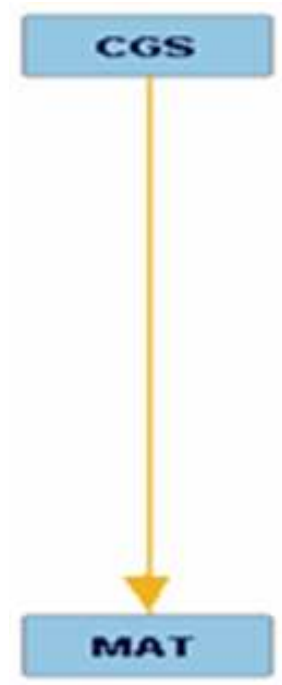

Fig. 3. Results from the directed acyclic graphs 
Table 1. Results for reliability analysis

\begin{tabular}{|c|c|c|c|}
\hline Item & Item-total correlation & Cronbach's alpha & No of items \\
\hline$\overline{\text { CGS1 }}$ & 0.561 & 0.801 & 6 \\
\hline CGS2 & 0.561 & & \\
\hline CGS3 & 0.542 & & \\
\hline CGS4 & 0.576 & & \\
\hline CGS5 & 0.519 & & \\
\hline CGS6 & 0.654 & & \\
\hline MAT1 & 0.701 & 0.886 & 6 \\
\hline MAT2 & 0.682 & & \\
\hline MAT3 & 0.653 & & \\
\hline MAT4 & 0.752 & & \\
\hline MAT5 & 0.828 & & \\
\hline MAT6 & 0.607 & & \\
\hline
\end{tabular}

Table 2. Summary for regression analyses

\begin{tabular}{llcccr}
\hline Dependent variable & Independent variable & Coefficients & Standard error & t-statistics & $P_{\text {value }}$ \\
\hline MAT & C & 2.931 & 0.118 & 24.923 & 0.000 \\
& CGS & 1.304 & 0.138 & 9.439 & 0.000 \\
F-statistic $/ P_{\text {value }}$ & $89.101 / 0.000$ & & & 2.268 & 0.024 \\
CGS & C & 0.159 & 0.070 & 9.439 & 0.000 \\
F-statistic $/ P_{\text {value }}$ & MAT & 0.163 & 0.017 & & \\
\hline
\end{tabular}

\section{Discussion and Conclusion}

A couple of corporate governance structure and the adoption of management accounting techniques has been a major topic of research in corporate governance and management accounting and is suggested to have significant impact on firm performance. The relationship between corporate governance structure and the adoption of management accounting techniques is interdependent. Several previous studies have discussed and examined this relationship, but they conducted it in separate research models. To the best of our knowledge, no research has discussed and determined which directed edge of the mutual relationship between corporate governance structure and the adoption of management accounting techniques comes first. This research employs the advanced models of directed graph searches and directed acyclic graphs to investigate the mutual relationship between corporate governance structure and the adoption of management accounting techniques in a joint model. The model of directed graph searches could decide effect directions of a research model.

The outcomes reveal that there are two effect directions in the relationship between corporate governance structure and the adoption of management accounting techniques. Corporate governance structure affects and is also strengthened by the adoption of management accounting techniques. However, this model does not determine which effect direction occurs first. To effectively extract which effect direction comes first in the mutual relationship, the model of directed acyclic graphs is utilized. The results suggest that sound corporate governance structures are first the causality of adopting management accounting techniques in business. Then, these management accounting techniques will help to result in sustainable corporate governance structures.

This paper further carries out the regression analysis to statistically test each effect direction of the mutual relationship. The findings show that good corporate governance structure will induce managers more likely to adopt management accounting techniques in business. Subsequently, the information from the management accounting techniques will improve the effectiveness of corporate governance structure. This is consistent with the results from the previous studies as above mentioned (Seal, 2006; Christine et al., 2011; Mayanja and Van, 2011; Wang and Huynh, 2014). However, these studies only argue and investigate the mutual relationship between corporate governance and management accounting in separate research models. The findings of the current research are more comprehensive than those of these studies and the first to offer an overview of the complicated relationship between corporate governance and management accounting. The implications from the findings would allow organizational managers to make better decisions on the choice of good corporate governance practices as well as management accounting techniques in order to create competitive advantages in a dynamic and rapidly changing business environment like Vietnam.

There are some limitations of this study. First, the data is based on single informants from targeted firms. This may lead to bias problem, which could produce unreliable research results. Future research should employ a multi-informant research design to avoid this potential bias. Second, this research is conducted in Vietnam as a developing economy and the findings of 
this research are expected to be applied in other developing economies. However, business conditions may be quite different among developing economies, hence researchers as well as managers should generalize these findings with care.

\section{Acknowledgment}

This research was partially supported by my university, Tra Vinh University. I am sincerely thankful to my university and also to the respondents for their help in collecting the data for this research.

\section{References}

Agrawal, A. and S. Chadha, 2005. Corporate governance and accounting scandals. J. Law Economics, 48: 371-406. DOI: $10.1086 / 430808$

Al-Omiri, M. and C. Drury, 2007. A survey of factors influencing the choice of product costing systems in UK organizations. Manage. Account. Res., 18: 399-424. DOI: 10.1016/j.mar.2007.02.002

Ameer, B., 2013. Corporate governance- issues and challenges in Pakistan. Int. J. Academic Res. Bus. Social Sci., 3: 79-96.

Bhagat, S. and B. Bolton, 2008. Corporate governance and firm performance. J. Corporate Finance, 14: 257-273. DOI: 10.1016/j.jcorpfin.2008.03.006

Bhiman, A., 2009. Risk management, corporate governance and management accounting: Emerging interdependencies. Manage. Account. Res., 20: 2-5. DOI: 10.1016/j.mar.2008.11.002

Black, B.S., H. Jang and W. Kim, 2006. Does corporate governance predict firms' market values? Evidence from Korea. J. Law Econom. Organ., 22: 336-413. DOI: 10.1093/jleo/ewj018

Brown, L.D. and M.L. Caylor, 2004. The correlation between corporate governance and company performances, research study commissioned by institutional shareholder services, Inc.

Cadbury, A., 1992. The Cadbury Committee Reports: Financial Aspects of Corporate Governance. 1st Edn., Burgess Science Press, London.

Cadbury, A., 2000. The corporate governance agenda. Corporate Governance, 8: 7-15. DOI: $10.1111 / 1467-8683.00175$

Cassell, C., G.A. Giroux, L.A. Myers and T.C. Omer, 2012. The effect of corporate governance on auditor-client realignments. Audit. J. Practice Theory, 31: 167-188.

Chand, M. and A. Dahiya, 2010. Application of management accounting techniques in Indian small and medium hospitality enterprises: An empirical study. Int. J. Entrepreneurship Small Bus., 11: 25-41. DOI: 10.1504/IJESB.2010.034430
Christine, D., F.D. Birgit and M. Christine, 2011. Corporate governance and management accounting in family firms: Does generation matter. Int. J. Bus. Res.

Cinquini, L., P. Collini, A. Marelli and A. Tenucci, 2008. An exploration of the factors affecting the diffusion of advanced costing techniques: A comparative analysis of two surveys (1996-2005). Proceedings of the 31 st Annual Congress of the European Accounting Association, Campus of Erasmus University, Rotterdam, Nederland.

Cromie, S., B. Stephenson and D. Monteith, 1995. The management of family firms: An empirical investigation. Int. Small Bus. J., 13: 11-34. DOI: $10.1177 / 0266242695134001$

Donna, F., H. Mahler and S. Cohen, 2011. How to conduct effective pretests. AIDSCAP's Behavior Change Communication (BCC) Unit, USA

Edwards, M. and R. Clough, 2005. Corporate Governance and Performance: An Exploration of the Connection in a Public Sector Context. 1st Edn., University of Canberra, Canberra, pp: 35.

Fullerton, R.R. and C.S. McWatters, 2001. The production performance benefits from JIT implementation. J. Operations Manage., 19: 81-96. DOI: 10.1016/S0272-6963(00)00051-6

Hyvonen, J., 2005. Adoption and benefits of management accounting systems: Evidence from Finland and Australia. Adv. Int. Account., 18: 97-120. DOI: $10.1016 / \mathrm{S} 0897-3660(05) 18005-2$

Johnson, H.T. and R.S. Kaplan, 1987. Relevance Lost: The Rise and Fall of Management Accounting. 1st Edn., Harvard Business Press, Boston, ISBN-10: 0875841384, pp: 269.

Kaplan, R.S., 1983. Measuring manufacturing performance: A new challenge for managerial accounting research. Account. Rev., 58: 686-705. DOI: $10.1007 / 978-1-4899-7138-814$

Kaplan, R.S. and M.E. Nagel, 2004. Improving Corporate Governance with the Balanced Scorecard. 1st Edn., Division of Research, Boston, pp: 9.

Kaplan, R.S. and D.P. Norton, 2007. Using the balanced scorecard as a strategic management system. Harvard Bus. Rev.

Kaymak, T. and E. Bektas, 2008. East Meets West? board characteristics in an emerging market: Evidence from Turkish Banks. Corporate Governance Int. Rev., 16: 550-561. DOI: $10.1111 /$ j.1467-8683.2008.00713.x

Lucas, M., 1997. Standard costing and its role in today manufacturing environment. Magazine Chartered Manage. Account., 75: 32-35.

Mayanja, M.K. and D.P.H.M. Van, 2011. Management accounting: An instrument for implementing effective corporate governance. Afr. J. Bus. Manage., 5: 12050-12065. 
Mayer, F., 1997. Corporate Governance, Competition and Performance. In: Enterprise and Community: New Directions in Corporate Governance, Deakin S. and A. Hughes (Eds.), Wiley, Oxford, ISBN-10: 0631205144, pp: 176.

Mia, L. and B. Clarke, 1999. Market competition, management accounting systems and business unit performance. Management Account. Res., 10: 137-158. DOI: $10.1006 /$ mare. 1998.0097

Mohamed, A.A. and T. Jones, 2014. Relationship between strategic management accounting techniques and profitability-a proposed model. Measuring Bus. Excellence, 18: 1-22.

DOI: 10.1108/MBE-04-2013-0023

Nicholson, G. and G. Kiel, 2007. Can directors impact performance? A case based test of three theories of corporate governance. Corporate Governance Int. Rev., 15: 585-608. DOI: 10.1111/j.1467-8683.2007.00590.x

Nunnally, J.C., 1978. Psychometric Theory. 1st Edn., McGraw-Hill, New York.

Otley, D.T., 1999. Performance management: A framework for management control systems research. Manage. Account. Res., 10: 363-382. DOI: $10.1006 /$ mare 1999.0115

Salvato, C. and L. Melin, 2008. Creating value across generations in family-controlled businesses: The role of family social capital. Family Bus. Rev., 21: 259-275. DOI: 10.1177/08944865080210030107
Seal, W., 2006. Management accounting and corporate governance: An institutional interpretation of the agency problem. Manage. Account. Res., 17: 389-408. DOI: 10.1016/j.mar.2006.05.001

Sgroi, F., A.M. Di Trapani, R. Testa and S. Tudisca, 2014. Strategy to increase the farm competitiveness. Am. J. Agricul. Biological Sci., 9: 394-400. DOI: 10.3844/ajabssp.2014.394.400

Testa, R., A.M. Di Trapani, F. Sgroi and S. Tudisca, 2014. Economic analysis of process innovations in the management of olive farms. Am. J. Applied Sci., 11: 1486-1491.

DOI: 10.3844/ajassp.2014.1486.1491

Wang, D.H.M. and Q.L. Huynh, 2014. Linkages among corporate governance, management accounting practice and organizational performance. Romanian Economic Bus. Rev., 9: 63-81

Williams, J.J. and A.E. Seaman, 2002. Management accounting systems change and departmental performance: The influence of managerial information and task uncertainty. Manage. Account. Res., 13: 419-445. DOI: 10.1006/mare.2002.0199 